\title{
UPORABA MODERNIH TEHNOLOGIJA KAO RIZIK ZA SEKSUALNO ZLOSTAVLJANJE I ISKORIŠTAVANJE DJECE I ADOLESCENATA PUTEM INTERNETA
}

\author{
Ana Raguž \\ Gordana Buljan Flander \\ Vlatka Boričević Maršanić \\ Poliklinika za zaštitu djece i mladih Grada Zagreba \\ E-mail:ana.raguz@poliklinika-djeca.hr
}

\begin{abstract}
SAŽETAK
Napredak tehnologije u zadnjih dvadesetak godina nedvojbeno je promijenio način života pa tako i način odrastanja djece i mladih, a uporaba interneta postala je sastavnim dijelom svakodnevnih životnih aktivnosti. Korištenje modernim tehnologijama, osobito u okviru rizičnih online aktivnosti, u ovom će radu biti razmotreno kao rizik u kontekstu odrastanja, a od rizičnih ponašanja razmatrat će se seksting (engl. sexting), odnosno izmjenjivanje seksualnih sadržaja, seksualna prisila $\mathrm{i}$ iznuda (engl. sextortion) kao iznuđivanje seksualnih sadržaja te vrbovanje ili mamljenje (engl. grooming) ${ }^{1}$ kao zavođenje ili namamljivanje maloljetne osobe. Svi rizici bit će detaljno analizirani u kontekstu seksualnog zlostavljanja i iskorištavanja putem interneta međusobnom povezanošću, razmatranjem posljedica kao i ulogom stručnjaka iz multikulturalne perspektive. Razvoj modernih tehnologija, kao i mogućnosti koje donosi, posebno u pandemiji, predstavljaju plodno tlo za ozbiljne prijetnje mentalnom zdravlju djece i mladih, ali i postavljaju zahtjeve pred sve one koji se bave zaštitom djece i mladih da kreiraju i razvijaju nove sustave zaštite djece.
\end{abstract}

Ključne riječi: seksualno zlostavljanje i iskorištavanje na internetu, online seksualna rizična ponašanja, mentalno zdravlje, pandemija, uloga stručnjaka

\section{UVOD}

Djeca već od najranije dobi borave pred ekranima, a rezultati istraživanja u Hrvatskoj pokazuju da pred ekranima provodi vrijeme gotovo $60 \%$ djece s navršenom jednom godinom, skoro $90 \% \mathrm{u}$ dobi od dvije godine i gotovo sva trogodišnja djeca predškolske dobi (Roje Đapić, Buljan Flander i Selak Bagarić, 2020). Ukupno vrijeme koje djeca provode pred ekranima, kao i dob korištenja internetom razlikuje se s obzirom na metodologiju kojom se koriste $u$ istraživanjima zbog čega se

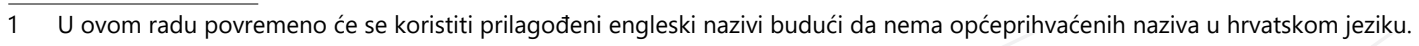


dobivaju različite procjene no variraju od 40 do gotovo 90\% (Holloway, Green i Livingstone, 2013). Prosječno vrijeme provedeno pred ekranima kod djece predškolske dobi u Hrvatskoj je oko dva i pol sata radnim danom te tri sata vikendom (Roje Đapić, Buljan Flander i Selak Bagarić, 2020). Nadalje, rezultati ovog istraživanja upućuju da se gotovo svako drugo dijete $(43,4 \%)$ samostalno koristi internetom. Podatci iz drugih europskih zemalja pokazuju da se djeca predškolske dobi ekranima koriste od 20 minuta do nekoliko sati (Holloway, Green i Livingstone, 2013). Sve veća prisutnost i korištenje uređajima s mogućnostima povezivanja na internet kod djece predškolske dobi povećava i vjerojatnost izloženosti rizicima povezanim s korištenjem internetom, a pokazuje se da djeca do devete godine nemaju kapacitet korištenja internetom na siguran i odgovoran način što ih može dovesti u potencijalnu opasnost (Holloway, Green i Livingstone, 2013).

Istraživanje HR Kids Online provedeno 2017. godine pokazalo je da gotovo polovica djece u dobi od 9 do 11 godine, dvije trećine djece u dobi od 12 do 14 godine te tri četvrtine djece u dobi od 15 do 17 godine mogu pristupiti internetu uvijek kada to žele ili trebaju (Ciboci, i sur., 2020). U Hrvatskoj gotovo svi adolescenti imaju pristup internetu od kuće (99,5\%), putem mobitela $(95,1 \%)$, a $77,9 \%$ u školi (Poliklinika za zaštitu djece i mladih Grada Zagreba, 2019). Istraživanja provedena na djeci osnovnoškolske i srednjoškolske dobi pokazuju da se vrijeme i način uporabe elektroničkih uređaja povećava s dobi, odnosno prema istraživanju provedenom u 19 zemalja na razini Europe (Ciboci i sur., 2020; Smahel i sur., 2020) djeca u dobi od 15 do 16 godina u usporedbi s mlađom djecom od 9 do 11 godina (a zbog značajnije uporabe pametnih telefona kao prijenosnih uređaja povezanih s internetom) češće se koriste njima i provode oko dvaput više vremena online. Također, u okviru istraživačkog projekta Subjektivna dobrobit djece u Hrvatskoj (Ajduković, Rajhvajn Bulat, Sušac i Vejmelka, 2020) pokazalo je da učestalost korištenja društvenim mrežama očekivano raste s dobi. Dobiveno je da u drugom razredu osnovne škole društvene mreže svaki dan koristi 35,3\%, u četvrtom razredu gotovo polovica $(49,0 \%)$ učenika koristi društvene mreže, u šestom razredu 63,1\% učenika društvene mreže koristi svakodnevno. Djeca u dobi od 9 do 17 godina u najvećoj mjeri pristupaju internetu putem vlastitih pametnih telefona, računala, laptopa ili notebooka, a tek nešto manji broj djece pristupa internetu putem tableta i igraćih konzola (Smahel i sur., 2020).

S napretkom tehnologije čini se da se povećava i vrijeme korištenja internetom, odnosno rezultati na razini Europe (Haddon, Livingstone i EU Kids Online network, 2012) pokazuju da je prije desetak godina vrijeme provedeno na internetu variralo od sat do dva dnevno. Također, rezultati istraživanja provedenog u Hrvatskoj 2013. godine pokazali su da $47 \%$ djece i mladih provodi jedan do dva sata dnevno na Facebooku, 34\% manje od pola sata, a 19\% na Facebooku provede tri ili više sati. Prema rezultatima istraživanja HR Kids Online (Ciboci i sur., 2020) više od četiri sata na internetu provede svako četvrto dijete od 9 do 17 godina tijekom radnog tjedna, odnosno više od jedne trećine djece tijekom vikenda. Podatci dobiveni samo na uzorku srednjoškolaca govore o trendu porasta korištenja internetom s dobi, odnosno svaki treći adolescent društvene mreže koristi od tri do pet sati dnevno, a svaki peti adolescent više od pet sati dnevno (Poliklinika za zaštitu djece i mladih Grada Zagreba, 2019). lako s metodološke strane neka od istraživanja mjere općenitu uporabu interneta, a neka korištenje društvenim mrežama, ispitivanjem načina korištenja pokazuje se da mladi najčešće navode da vrijeme na internetu provode gledajući videozapise, komunikaciji i dopisivanju s drugima (Smahel i sur., 2020; Ciboci i sur., 2020), a što upravo ostvaruju uporabom društvenih mreža. Pregledom literature razvidno je da je većina autora stava da su rezultati barem 
djelomično usporedivi. No, iako su digitalne tehnologije izvor brojnih prednosti i mogućnosti poput lakoće i brzine komuniciranja, učenja, dostupnosti informacija, razvoja vještina i interesa, djeci i mladima mogu predstavljati i prijetnje za mentalno zdravlje.

Situacija pandemije više nego ikad ranije olakšala je pristup potencijalnim žrtvama bez prisutnosti stvarnih zaštitnika i stručnjaka zbog lockdowna te značajno povećala rizik za doživljavanje raznih oblika seksualnog zlostavljanja i iskorištavanja putem interneta. Premda postoje brojna ponašanja u području problematične uporabe interneta djece i mladih, u ovom radu naglasak će biti na elektroničkom nasilju i seksualno rizičnim oblicima online ponašanja. Stoga, cilj ovog rada je ne samo sintetizirati nego i razmotriti dostupne spoznaje o različitim seksualno rizičnim ponašanjima online povezanim s oblicima seksualnog zlostavljanja i iskorištavanja djece i adolescenata putem interneta koje predstavljaju ozbiljne rizike za mentalno zdravlje. Tema seksualnog zlostavljanja i iskorištavanja postala je sve važnija sa značajnijom uporabom interneta i korištenja digitalnim tehnologijama, no u vrijeme pandemije kada izvješća INTERPOL-a i EUROPOL-a upozoravaju na značajno povećanje razmjene slika seksualnog iskorištavanja djece putem interneta te pozivaju na sustavnu i promptnu zaštitu i edukaciju stručnjaka, iznimno je važna.

\section{RIZICI ODRASTANJA U DOBU MODERNIH TEHNOLOGIJA - ELEKTRONIČKO NASILJE I ONLINE SEKSUALNO RIZIČNA PONAŠANJA}

\section{Elektroničko nasilje}

Brojna istraživanja povezuju sve veću uporabu interneta s online rizičnim ponašanjima, a upravo jer se internet, odnosno društvene mreže najčešće koriste za komunikaciju s drugima, odnosno upoznavanjem novih ljudi (Gómez i sur., 2017; Machimbarrena i sur., 2018). Jedan od najistraženijih rizika s kojim se djeca i mladi mogu suočiti korištenjem tehnologija je upravo elektroničko nasilje koje se odnosi na ponašanja poput javnog vrijeđanja i izrugivanja na internetu, zastrašivanja, prijetnji, širenja laži ili ugrožavanja ugleda, kao i objavljivanja i prosljeđivanja poruka, fotografija i videa bez pristanka i/ili znanja osobe (Brewer i Kerslake, 2015; Machimbarrena i Garaigordobil, 2018). Pregledom 159 studija o prevalenciji elektroničkog nasilja autori navode da je pojavnost nasilja kod mladih putem interneta u prošloj godini varirala od 1\% do 61\% (Brochado, Soares i Fraga, 2017). Velika diskrepancija u prevalenciji može se objasniti višestrukim razlozima: različita operacionalizacija konstrukta elektroničkog nasilja, korištena metodologija, različita pouzdanost i valjanost korištenih instrumenata kao i dob i spol ispitanika koji čine uzorak, a što je vidljivo i proučavanjem dostupne literature (Chun, Lee, Kim i Lee, 2020).

\section{Online seksualna rizična ponašanja}

Osim elektroničkog nasilja kao jednog od najprepoznatljivijih i istraživanijih konstrukata, rizična ponašanja na internetu predstavljaju i dopisivanje, dijeljenje osobnih podataka ili informacija s nepoznatim osobama, seksting, iznuđivanje, uznemiravanje, prijetnje, širenje laži i sl. (Notten i Nikken, 2016) kao i susreti u offline svijetu s osobama koje su upoznali putem društvenih mreža (Wurtele i Kenny, 2016). Istraživanja pokazuju da mladi na društvenim mrežama najčešće komuni- 
ciraju s osobama koje nikada nisu upoznali u stvarnom životu ili su im tek poznanici (Sklenarova i sur., 2018), što potvrđuju i rezultati istraživanja u Hrvatskoj. Gotovo $70 \%$ adolescenata putem društvenih mreža dopisivalo se s osobama koje su upoznali online, a $35 \%$ mladih otišlo na susret s osobom koju su upoznali putem društvenih mreža (Poliklinika za zaštitu djece i mladih Grada Zagreba, 2019). Porastu online rizičnih ponašanja među djecom i mladima svjedoči podatak da je 2017. godine 30\% djece u dobi od 9 do 17 godina u posljednjih godinu dana komuniciralo na internetu s osobama koje nisu upoznali uživo, odnosno svako četvrto dijete u dobi od 15 do 17 godina se u posljednjih godinu dana susrelo uživo s osobom koju su upoznali na internetu (Ciboci i sur., 2020). Za usporedbu, rezultati iz 2013. godine (Hrabri telefon i Poliklinika za zaštitu djece i mladih Grada Zagreba, 2013) pokazuju da je tek $8 \%$ djece i mladih otišlo na susret s nepoznatom osobom koju su upoznali na Facebooku.

Rane godine adolescencije uz brojne razvojne promjene na psihološkoj, biološkoj i socijalnoj razini dovode i do otkrivanja vlastite seksualnosti, a što mladi najčešće čine putem interneta, dobrovoljno se uključujući u online seksualne aktivnosti (Sklenarova i sur., 2018). S obzirom da se radi o online komunikaciji, mladi, za razliku od komunikacije licem u lice, lakše otkrivaju svoje intimne misli i iskustva vezana uz seksualnost (Wolak i sur. 2010), no istovremeno zbog karakteristika adolescencije koje se odnose na osjećaje prividne neranjivosti, nerijetko se istovremeno mogu izložiti različitim rizičnim situacijama (Burén i Lunde, 2018). Unatoč potencijalnim prednostima u kontekstu normativnog razvoja i edukacije u kontekstu seksualnosti, korištenje internetom u društvene i seksualne svrhe može povećati rizik od viktimizacije adolescenata, a procjene su da je jedno od petero djece doživjelo neki oblik negativnoga seksualnog iskustva na internetu (Livingstone i Smith, 2014; MUP, 2020). Seksualno rizična ponašanja na internetu najčešće se odnose na sudjelovanje u seksualnim chatovima, traženju seksualnih sadržaja, (ne)namjernom izlaganju seksualnim sadržajima kao i sudjelovanju u sekstingu (Ballester-Arnal i sur., 2016; Mitchell i sur., 2012).

U literaturi, među istraživačima kao i praktičarima, ne postoji jasan konsenzus oko jasnoće definiranja svih pojmova, no u ovom radu korištene su definicije i pojmovi koji su literaturom najprihvaćeniji.

\section{Seksting}

Pozornost istraživača u posljednjih nekoliko godina ponajviše zaokuplja seksting (engl. sexting), odnosno primanje, slanje (Barrense-Dias i sur., 2017; Van Ouytsel i sur., 2018), ali i prema nekim autorima i prosljeđivanje seksualno sugestivnih ili eksplicitnih sadržaja - fotografija, videa i poruka putem mobitela ili interneta. Seksting je još početkom desetljeća prepoznat kao rizično ponašanje (Mitchell i sur., 2007; 2012) i od tada je intenzivno proučavan u kontekstu vršnjačkog nasilja i iznuđivanja, a kasnije i u kontekstu seksualnog zlostavljanja (Morelli i sur., 2016; Sklenarova i sur., 2018; De Santisteban i Gámez-Guadix, 2018; Wolak i sur., 2018) zbog čega će u ovom radu biti detaljno pojašnjen. Seksting podrazumijeva i razmjenu samostalno izrađenog seksualno eksplicitnog sadržaja (engl. self generated explicit material) no prema Luksemburškim smjernicama (2016) postoji potencijalni rizik kod korištenja termina samostalno izrađenog za razliku od prisilnog materijala jer može dovesti do poimanja da je dijete krivo za zlostavljanje pa prema tome iako djeca (posebno adolescenti) mogu samostalno i samoinicijativno generirati seksualni sadržaj, to ne 
znači da su suglasna s neprimjerenim ili štetnim korištenjem i/ili distribucijom tih slika ili kao i da su odgovorna za to.

Istraživanja pokazuju da prevalencija sekstinga varira od 9,6\% do 54\% (Van Ouytsel i sur., 2017; Barrense-Dias i sur., 2017) pri čemu se čini da stope prevalencije sekstinga ponajviše ovise o različitosti definiranja, odnosno operacionalizaciji koncepta. Naime, neki autori kao mjeru sekstinga uzimaju prevalenciju slanja koja je u tom slučaju niža, no primjetno je da se stope prevalencije značajno povećaju kada istraživači mjere i slanje i primanje seksualno sugestivnih sadržaja. Recentna metaanaliza pokazuje da je seksting relativno čest oblik ponašanja među adolescentima, oko $15 \%$ mladih šalje, 28\% prima poruke seksualnog sadržaja (Madigan i sur., 2018). Istraživanje Poliklinike za zaštitu djece i mladih Grada Zagreba (2019) pokazuje da čak 54,7\% učenika 1. i 3. razreda srednjih škola s područja Hrvatske izjavljuje da je jednom ili više puta na svoj uređaj dobilo seksualno izazovnu poruku, a 5,8\% barem jednom slalo takve poruke.

Sekstanje kod mladih upravo jer se događa online i iza ekrana olakšava i potiče dijeljenje osjećaja seksualnog uzbuđenja (Van Ouytsel i sur., 2017; Van Ouytsel, Walrave i Ponnet, 2019), a istraživanja pokazuju da se kao najčešći motivi sekstanja kod adolescenata pokazuju: prirodan interes za razumijevanje vlastite seksualnosti i seksualnih aktivnosti, pokazivanje interesa u romantičnim odnosima, percepcija sekstinga kao normativne vršnjačke aktivnosti, zabava, privlačenje pažnje i pobuđivanje ugodnih emocija kod partnera (Bianchi i sur., 2017; Van Ouytsel, Walrave i sur., 2018; Burén i Lunde, 2018; Maheux i sur., 2020; Walker, Sanci i Temple-Smith 2013; Kandel Englander i McCoy, 2017; Kričkić, Šincek i Babić Čike, 2017), a slični rezultati dobiveni su i u Hrvatskoj (Poliklinika za zaštitu djece i mladih Grada Zagreba, 2019). Prema Bianchi i suradnicima (2018) sve navedeno moguće je promatrati trima primarnim vrstama motivatora: motivima vezanim uz seksualnost, motivima traženja potvrde tjelesnog izgleda te instrumentalnim motivima.

Međutim, iako su generalno motivi sekstanja zajednički većini mladih, studija Englandera i McCoya (2017) pokazuje da više od polovine mladih koji su bili uključeni u seksting navodi da su doživjeli neki oblik prisile ili nasilja da se u njega uključe. Povezano s tim, utvrđene su spolne razlike u doživljaju sekstinga s obzirom na spol (van Oosten, Vandenbosch i Peter, 2017), odnosno djevojke za razliku od mladića osjećaju manje zadovoljstvo dok sekstaju, vjerojatnije je da će osjećati pritisak te izvještavaju o većoj zabrinutosti zbog potencijalne ugroze vlastite reputacije. Također, djevojke u većoj mjeri doživljavaju iznuđivanje ili pritisak zbog nastavka ili započinjanja sekstinga (Jørgensen i sur., 2018). Novija istraživanja nalaze da mladi najčešće izvještavaju o ugodnim seksualnim iskustvima kada se radi o komunikaciji s osobama iste dobi ili nešto starije (Jonsson i sur., 2019). Pojedini autori (Morelli i sur., 2016; Wolak, Finkelor i Mitchell, 2012; Cooper i sur., 2016) predlažu sagledavanje sekstinga u dvije kategorije: seksting kao eksperimentiranje (romantično-istraživački aspekt) i seksting kao prisila i nagovor (zlostavljajuće-eksploatacijski aspekt), što i u metodološkom smislu otvara mogućnosti za povezivanje i daljnje istraživanje tih koncepata, ali i njihovih posljedica. Dakle, usprkos brojnim mogućnostima i očekivanoj motivaciji upuštanja u seksting u adolescentnoj dobi, druga navedena kategorija sekstinga može predstavljati ozbiljan rizik za adolescente, tj. biti sredstvo koje vodi do iznuđivanja ili prisile slanja seksualno sugestivnih sadržaja, kao i online viktimizacije, odnosno može se poimati kao online ekstenzija tradicionalnih oblika seksualnog iskorištavanja. 


\section{Grooming}

Vrbovanje ili namamljivanje (engl. grooming) proces je kojim odrasla osoba, najčešće putem elektroničkih medija pristupa djetetu, zadobiva njegovo povjerenje ne bi li ga privoljela na uključivanje u seksualiziranu komunikaciju, dijeljenje seksualiziranih sadržaja odnosno na uključivanje u (seksualne) zlostavljačke aktivnosti putem interneta i/ili uživo (Craven, Brown i Gilchrist, 2006; Gámez-Guadix, Borrajo i Almendros, 2016). U hrvatskom zakonodavstvu u kaznena djela "Iskorištavanje djece za pornografiju" iz članka 163. Kaznenog zakona uključeno je vrbovanje (MUP, 2021). Počinitelji u tom procesu koriste strategije koje uključuju razvijanje posebnog odnosa povjerenja s djetetom, nježno pomicanje granica, seksualizirane razgovore, emocionalne ucjene, traženje da se čuvaju tajne, stvaranje osjećaja krivnje, potkupljivanja i prijetnje (Craven, Brown i Gilchrist, 2006) djetetu. Počinitelji suptilnim strategijama komunikacije dovode do razvoja povjerenja, povećavaju vjerojatnost da se dijete desenzitizira, odnosno osnažuju uvjerenja da se ovakav odnos ne razlikuje od bilo kojeg drugog odnosa (Kloess, Beech i Harkins, 2014). Online grooming, najčešće kasnije u fazi kada je već izgrađen odnos povjerenja, uključuje i seksualnu solicitaciju odnosno uključivanje djeteta u seksualizirane razgovore i aktivnosti, ali i dobivanje intimnih informacija o djetetu (De Santisteban i Gámez-Guadix, 2018; Mitchell, Finkelhor i Wolak, 2007; Whittle i sur., 2013).

Prilikom razmatranja procesa groominga neizbježno je spomenuti seksualnu solicitaciju koja se najčešće odnosi na uključivanje u seksualno eksplicitne ili sugestivne razgovore, razmjenu privatnih, pornografskih ili erotskih slika, opisivanje seksualnih aktivnosti ili sudjelovanje u cyberseksu, druženja i seksualne aktivnosti uživo (Livingstone i sur., 2011). Prevalencija seksualne solicitacije u dobi do 12 do 17 godina procjenjuje se od 7 do 23\% (Mitchell, Wolak i sur., 2007; Bergen i sur., 2014; Sklenarova, 2018; Gámez-Guadix i Mateos-Pérez, 2019), a prema retrospektivnim studijama seže do 65\% (Greene-Colozzi i sur., 2020). lako nagovaranje ili solicitaciju djeca mogu doživjeti od svojih vršnjaka, nagovori ili zahtjevi odrasle osobe promatraju se u drukčijem kontekstu upravo zbog razlike u moći, znanju, odnosno radi se o zakonskoj vrsti odnosa i seksualna solicitacija sagledava se kao komponenta online mamljenja ili vrbovanja (tzv. online groominga).

Opseg kontakata žrtve s počiniteljem može varirati od jednog kontakta do kontinuirana održavanja odnosa (Kloess i sur., 2017; Van Gijn-Grosvenor i Lamb, 2016), a to je ujedno razlika između seksualne solicitacije, koja je ponašanje, i groominga koji je proces koji se sastoji od brojnih faza: odabir žrtve, razvoj povjerenja, desenzitizacija i seksualni sadržaj. Kod djece kod koje se proces zavođenja, tzv. vrbovanja ostvaruje tijekom duljeg vremena vjerojatno će dovesti do toga da dijete doživljava ambivalentne osjećaje prema počinitelju, a što potencijalno može odgoditi razotkrivanje zbog srama i krivnje (Joleby i sur., 2021). Taj mehanizam u svojoj osnovi vrlo je sličan i kod seksualnog zlostavljanja u tradicionalnom smislu.

Procjenjuje se da se je u dobi od 12 do 15 godina prevalencija groominga oko 7\% (Gámez-Guadix i sur., 2018). Velika retrospektivna studija pokazuje da je $23 \%$ djece i mladih tijekom odrastanja doživjelo online grooming (Greene-Colozzi i sur., 2020). Velika diskrepancija u prevalenciji može biti povezana upravo s vremenskim odmakom i poimanjem doživljenih iskustava, osnaženosti izlaskom iz akutnog doživljavanja traumatskog iskustva same žrtve. Uzimajući u obzir podatke EUROPOL-a i INTERPOL-a da je pandemija dodatno pogodovala online groomingu i sivu zonu brojki ovog po- 
dručja, odnosno jako mali broj prijavljenih djela na štetu djeteta, stvarne pokazatelje iz sadašnjeg perioda tek će biti moguće vidjeti u sljedećim godinama retrospektivnim studijama.

\section{Seksualna prisila i iznuda na internetu}

Seksting također povećava vjerojatnost seksualne prisile i iznude na internetu (engl. sextortion), najčešće da će se objaviti ili proslijediti postojeći seksualni sadržaji žrtve ako se žrtva na neki način ne uključi u daljnje seksualne aktivnosti (Patchin i Hinduja, 2018; Wolak. i sur., 2017; Wolak i sur., 2018; De Santisteban i Gámez-Guadix, 2018). Često je korišten termin predmet debate u području zaštite djece jer ne daje jasno do znanja da je u pitanju seksualno iskorištavanje djeteta i nosi rizik trivijalizacije djela (Interagency Working Group on Sexual Exploitation of Children, 2016). Istraživanja pokazuju da više od polovice žrtava seksualne prisile i iznude na internetu poznaje počinitelje: većina počinitelja su bivši ili trenutni romantični/seksualni partneri, slijede ih prijatelji i poznanici žrtava, a najmanje počinitelja čine osobe koje žrtve nikad nisu upoznale (Wolak i sur., 2017). Unatoč tomu što žrtve sekstortiona najčešće provobitno iz svog doživljaja bez jasne prisile, tijekom procesa groominga, šalju sadržaj svojim romantičnim partnerima, 2/3 njih kažu da su to činili pod pritiskom i na nagovor partnera (Wolak i sur., 2018). U Hrvatskoj je gotovo svaki peti adolescent sekstao pod nagovorom ili prisilom, 13,4\% mladih na nagovor, a 4,4\% pod prisilom, a nagovor je najčešće potican od partnera/ice, potom od prijatelja, nekoga tko im se sviđa i poznaju ga uživo, od nekoga tko im se sviđa i ne poznaju ga uživo (Poliklinika za zaštitu djece i mladih Grada Zagreba, 2019). Prema rezultatima istraživanja u Hrvatskoj je sa znatno starijom osobom seksualno izazovan materijal razmjenjivalo $5,4 \%$ adolescenata, od čega je njih $87 \%$ navelo da je to činilo dobrovoljno, $7 \%$ na nagovor te $6 \%$ pod prisilom (Poliklinika za zaštitu djece i mladih Grada Zagreba, 2019), no imajući u vidu sve navedeno jasno je da podatak o dobrovoljnosti govori samo o aktualnom doživljaju djeteta posredovanim vrbovanjem, a ne i o zakonskoj regulativi, odnosno govoreći u konkretnim terminima - izmjena seksualnog sadržaja s odraslom osobom predstavlja seksualno zlostavljanje putem interneta.

\section{Seksualno zlostavljanje $\mathrm{i}$ iskorištavanje djece na internetu}

Seksualno zlostavljanje djece na internetu (engl. online child sexual abuse) jedno je od najtežih oblika zlostavljanja djeteta u digitalnom okruženju, a uključuje bilo koji oblik seksualnog zlostavljanja djece koji ima poveznicu s mrežnim okruženjem, odnosno seksualno zlostavljanje putem interneta odnosi se na seksualiziranu komunikaciju putem interneta, dobivanje ili dijeljenje seksualno eksplicitnih sadržaja putem slika ili videozapisa bez pristanka, kao i distribuciju seksualnog sadržaja koji se dogodio uživo (Baumgartner, Sumter, Peter, Valkenburg i Livingstone, 2014; Owens, Eakin, Hoffer, Muirhead i Shelton, 2016). Prema Luksemburškim terminološkim smjernicama za zaštitu djece od seksualnog iskorištavanja i seksualnog zlostavljanja (Interagency Working Group on Sexual Exploitation of Children, 2016) seksualno zlostavljanje putem interneta može biti „bilo koji oblik seksualnog zlostavljanja djece koje ima vezu s internetskim okruženjem" pri čemu se navodi da seksualno zlostavljanje putem interneta nije novi i poseban oblik seksualnog zlostavljanja, odnosno internet omogućava samo različite manifestacije seksualnog zlostavljanja djece i povećava dostupnost žrtava počiniteljima. Zbog navedenog se u terminološkim smjernicama preporučuje termin: seksualno zlostavljanje djece omogućeno internetom. Posljedica seksualne solicitacije i 
interakcije očituje se upravo u tome da će seksualni materijal moguće biti trajno dostupan na internetu, što može generirati tzv. dječju pornografiju², kao i uzrokovati viktimizaciju jer se sadržaj ne može eliminirati (Nur Say i sur., 2015).

Prema EUROPOL-ovoj definiciji, seksualno iskorištavanje djece odnosi se na "seksualno zlostavljanje osobe mlađe od 18 godina, kao i na proizvodnju slika takvog zlostavljanja i dijeljenje tih slika na internetu" (EUROPOL, 2020) je dosta široka i podrazumijeva brojne podređene koncepte u svom određenju. Također, prema EUROPOL-u (2020) seksualno iskorištavanje djece ne uključuje uvijek kontakt (bilo online ili offline) što je novije shvaćanje nastalo razvojem tehnologija. Nadalje, ono što razlikuje koncept seksualnog iskorištavanja djece od drugih oblika seksualnog zlostavljanja djece jest osnovni pojam razmjene koja je prisutna kod iskorištavanja (Interagency Working Group on Sexual Exploitation of Children, 2016).

Ključne specifičnosti zlostavljanja putem interneta uključuju neravnotežu moći u smislu posjedovanja određenih sadržaja poput podataka, slika i videa te superiornosti počinitelja u digitalnim kompetencijama i mogućnosti "anonimnog" djelovanja (Shariff i Gouin, 2006; Vandebosch i Van Cleemput, 2008). Nadalje, u virtualnom svijetu višestruka i opetovana viktimizacija je neizbježna i vjerojatna zbog same naravi virtualnog svijeta (Vejmelka, Strabić i Jazvo, 2017). U slučaju elektroničkog nasilja, snaga počinitelja ne leži u fizičkoj nadmoćnosti nad žrtvom, već u tehnološkoj snalažljivosti i upućenosti što stvara novu dinamiku između počinitelja i žrtve, ali i odgovornih osoba koje gube moć nad počiniteljem kada ne mogu pratiti korak s tehnološkim novostima (Starcevic i Aboujaoude, 2015).

\section{MEĐUSOBNA POVEZANOST ONLINE RIZIKA}

Brojna istraživanja (Reyns i sur., 2013; Jasso i sur., 2018; DeSantisteban i Gámez-Guadix, 2018; Gámez-Guadix i Mateos-Pérez, 2019) pokazala su da je seksting povezan s povećanjem vjerojatnosti doživljavanja elektroničkog nasilja. Primjerice, seksualni sadržaj koji je u početku kreirao dobrovoljno kasnije se može širiti bez pristanka ili se može koristiti za ucjenu ili na drugi način prijetnjom djetetu - žrtvi, odnosno dijete postaje žrtvom procesa seksualne iznude daljnjih sadržaja (Walker i Sleath, 2017; Wolak i sur., 2018). Neki od načina na koje se elektroničko nasilje može manifestirati u kontekstu sekstinga su: da počinitelj nastavlja kontaktirati žrtvu usprkos zahtjevu da to više ne čini, pokušava uspostaviti neželjeni seksualni kontakt, prijeti nasiljem i sudjeluje u uznemiravanju žrtve.

Nadalje, o povezanosti rizičnih ponašanja govori u prilog i to da iskustvo elektroničkog nasilja predviđa uključivanje u aktivnosti seksting, odnosno da se seksting javlja posljedično kao rezultat pritiska, zlostavljanja i/ili prisile u vidu traženja i nastavka slanja sadržaja (Van Ouytsel i sur., 2017). Nedavno longitudinalno istraživanje Gámez-Guadixa i Mateos-Péreza (2019) pokazalo je među uzorkom mladih između 12 i 14 godina navedeno karakteristično samo za mladiće, odnosno mladići se koriste razmjenom seksualnih sadržaja kao strategijom povećanja socijalnog statusa, a što je u skladu s rezultatima istraživanja da je jedna od posljedica elektroničkog nasilja upravo smanjenje samopouzdanja i javljanje depresivne simptomatologije (Hinduja i Patchin, 2011; Kowalski

2 Preporučeni naziv za dječju pornografiju je materijal o seksualnom zlostavljanju djece, no ovdje se izraz dječja pornografija koristi radi jasnoće pojave i u okviru hrvatskog zakonodavstva. 
i sur., 2014). Detaljnije objašnjenje ovog nalaza vidljivo je i iz toga da je ova simptomatologija na emocionalnom planu povezana s predikcijom uključivanja u seksting (Temple i sur., 2014), a motiv sekstanja koji se odnosi na odobravanje drugih i socijalnu podršku te doživljaj privlačnosti (Eglander i McCoy, 2017) istovremeno se pokazuje kao češći motiv kod mladića nego kod djevojaka budući da se seksting u socijalnom okruženju kod djevojaka može doživljavati negativnim (Walker, Sanci i Temple, 2013).

Također, samostalno kreiranje seksualno eksplicitnog sadržaja (engl. Self generated explicit material) predviđa primanje seksualnih zahtjeva odrasle osobe nakon godinu dana (Gámez-Guadix i Mateos-Pérez, 2019). Ti rezultati potvrđuju prethodne empirijske dokaze da seksting prethodi primanju seksualnih zahtjeva odraslih, odnosno seksualne solicitacije odrasle osobe, što autori objašnjavaju time da je jedan od mogućih razloga da seksting povećava izloženost počiniteljima davanjem informacija ili intimnih slika, a koje se potom mogu koristiti za uznemiravanje ili prijetnju djetetu - žrtvi (Reyns i sur., 2013, Gámez-Guadix i Mateos-Pérez, 2019) zbog čega se nalazi povezanost između elektroničkog nasilja i solicitacije (Wachs i sur., 2017). Istovremeno, pokazuje se da je seksualna solicitacija prediktor uključivanja u seksting, a što se objašnjava sličnosti s tradicionalnim oblikom seksualnog zlostavljanja, odnosno traumatskom seksualizacijom kao posljedicom traume zlostavljanja (Gámez-Guadix i Mateos-Pérez, 2019; Paolucci, Genuis i Violato, 2001). Drugim riječima, seksualno zlostavljanje online, ali i u tradicionalnom smislu, povećava vjerojatnost da se mladi uključuju u seksualizirana ponašanja poput sekstinga jer počinitelji djecu nagovaraju ili namamljuju u seksualne aktivnosti tijekom dugog perioda kojeg opravdavaju i normaliziraju takva seksualizirana ponašanja, a sve da bi ih čim duže zadržali u takvom odnosu (Jonsson i sur., 2019; Mitchell i sur., 2008) pri čemu je proces progresivne seksualizacije zapravo jedan od elementa u procesu namamljivanja ili vrbovanja, tzv. groominga (De Santisteban, i sur., 2018).

\section{POSLJEDICE ZA MENTALNO ZDRAVLJE}

Posljedice online seksualnog zlostavljanja, odnosno viktimizacije povezane su s ozbiljnim posljedicama na emocionalnom i socijalnom planu (Hamilton i sur., 2017; Jonsson i sur., 2019). Istraživanje Klettke i suradnika (2019) upućuje da razmjenjivanje seksualnih sadržaja samo po sebi ne dovodi do negativnih posljedica za mentalno zdravlje, ali je slanje seksualno provokativnih poruka i slika pod prisilom ili nagovorom te dobivanje takvih poruka i slika kada su one neželjene povezano $s$ nižim samopoštovanjem, više simptoma stresa, depresije, anksioznosti, posttraumatskog stresnog poremećaja, suicidalnih misli i pokušaja suicida (O'Connor i sur., 2017). Iskustva poput elektroničkog nasilja i seksualne solicitacije povezuju se sa simptomima PTSP-a u $30-60 \%$ adolescenata (Dönmez i Soylu, 2019). Nadalje, neka istraživanja govore u prilog jednakim posljedicama s aspekta traume kao i kod tradicionalnih oblika seksualnog zlostavljanja koji uključuju penetracijski seksualni odnos (Hamilton i sur., 2017; Jonsson i sur., 2019), pri čemu najveće posljedice za mentalno zdravlje imaju djeca i mladi koji su istovremeno imali iskustva obiju vrsta seksualnog zlostavljanja, što podržava i potvrđuje model poliviktimizacije (Finkelhor, Ormrod i Turner, 2007). Navedena sličnost posljedica može se sagledati u tome da se seksualna solicitacija može promatrati kao beskontaktni oblik seksualnog zlostavljanja (Svjetska zdravstvena organizacija, 2003). Važno je napomenuti da brojni autori navode da su gotovo dvije trećine mladih koji doživljavaju elektroničko nasilje ujedno 
i žrtve nasilja među vršnjacima (Schneider, O'donnell, Stueve i Coulter, 2012), a što dodatno produbljuje postojeću simptomatologiju. Iskustvo ranije viktimizacije, neskladni i narušeni obiteljski i vršnjački odnosi, niže samopoštovanje, depresija te rizična online ponašanja i ženski spol (Mitchell i sur., 2007b; Mitchell, Finkelhor i Wolak, 2001; Whittle, Hamilton-Giachritsis i Beech, 2015; Wolak i sur., 2010) povećavaju vjerojatnost seksualne viktimizacije kod adolescenata, odnosno brojni rizici, posebice njihova kombinacija, povećavaju vulnerabilnost žrtve i time olakšavaju počiniteljima uspostavljanje inicijalnog odnosa sa žrtvom.

\section{SEKSUALNO ZLOSTAVLJANJE I ISKORIŠTAVANJE PUTEM INTERNETA KAO DRUŠTVENI PROBLEM}

Uzimajući u obzir da su najranjivija djeca upravo ona s iskustvom ranijih psihotraumatskih iskustava tijekom odrastanja, razvidno je da se razni pojedinci i psihosocijalni rizici isprepleću sa socijalnim rizikom načina korištenja modernim tehnologijama kao sastavnim dijelom odrastanja svih digitalnih generacija. Premda se značajna problematika u svijetu, ali i u Hrvatskoj, odvija vezano uz terminologiju ovih pojmova (Hamilton-Giachritsis, 2020; Vejmelka i Jurinić, 2020) te konsenzusa što pojedini oblici obuhvaćaju, jasno je da navedeni socijalni rizici predstavljaju realnu prijetnju (Ajduković, 2008; Adam, Beck i van Loon, 2000, prema Ajduković, 2008) jer je pregledom recentne i dostupne literature jasno da rizični oblici korištenja suvremenih tehnologija predviđaju potencijalna iskustva seksualnog zlostavljanja i iskorištavanja djece i mladih putem interneta.

Shodno razmatranjima, iako se nerijetko govori o novim oblicima izazova u kontekstu odrastanja i svijeta tehnologija, rizike /koji predstavljaju ozbiljnu prijetnju dječjem integritetu i odrastanju, jasno i nedvojbeno se odnose na djela na štetu djeteta, zakonski su kažnjiva i predstavljaju preduvjet za ozbiljan socijalni problem - seksualno zlostavljanje putem interneta/, potrebno je definirati u kontekstu društvene uvjetovanosti. Zabrinjavajuće je da međunarodni i domaći trendovi pokazuju porast u broju prijava kaznenih djela seksualnog zlostavljanja i iskorištavanja djece dok s druge strane broj pravomoćnih osuda ne prati taj rastući trend (Jurinić, Vejmelka i Galiot, 2020).

Bilo da je seksualno zlostavljanje i iskorištavanje tradicionalno sagledavano ili u kontekstu interneta ono predstavlja socijalni problem s obzirom da uzrokuje emocionalnu patnju, narušava vrednote i dovodi do društvenih i zakonskih reakcija i djelovanja (Ajduković, 2008). Seksualno zlostavljanje i iskorištavanje putem interneta zadovoljava sve uvjete definicije socijalnog problema, odnosno društveno je uvjetovana pojava, predstavlja stvarnu ili prijetnju određenim vrijednostima ili interesima djeteta, obitelji, ali i šire zajednice te ga je moguće spriječiti i smanjiti sustavnim djelovanjem kontinuirane intersektorske suradnje u kontekstu adekvatna zakonskog postupanja, pravodobnog prepoznavanja i u konačnici edukacije i podizanja javne svijesti što je posebno važno u kontekstu pandemije. 


\section{ULOGA STRUČNJAKA S ASPEKTA MULTIKULTURALNOSTI}

S obzirom da adolescenti gledaju na seksting kao normativno ponašanje u njihovoj dobi vjerojatnije je da će biti u takvim aktivnostima i manje inhibirani (Van Ouytsel i sur., 2019), a posljedično i manje oprezni oko potencijalnih rizika - ključna je uloga upravo svih onih koji sudjeluju u zaštiti djece i mladih iz svih sektora.

S aspekta multikulturalnosti (Žganec i Miljenović, 2011) kompetentan stručnjak nedvojbeno bi trebao usvajati nova znanja o svijetu suvremenih tehnologija, njegovim rizicima i specifičnostima odrastanja u ovom dobu, razvijati vještine koje mu omogućuju da što adekvatnije pristupi žrtvama i maloljetnim počiniteljima te im tako osigura stručnu pomoć i podršku koja im je u okviru uže i šire zajednice nužna. Kompetentan bi stručnjak također trebao raditi na podizanju javne svijesti posebice u smislu edukacije i destigmatizacije s obzirom da se osobe koje su žrtve online oblika nasilja na internetu često osuđuju, okrivljuju i na teret im se stavlja jednaka odgovornost kao i počinitelju.

Najprihvaćenija konceptualizacija multikulturalne kompetencije odnosi se na trodijelni model koji uključuje znanje, svjesnost i vještine stručnjaka (Sue, Arredondo, and McDavis, 1992; prema Pagnotta i sur., 2018; Žganec i Miljenović, 2011). Znanje se prema ovom modelu odnosi na nastojanje produbljivanja razumijevanja kulturne pozadine i svjetonazora klijenata. Dakle, prilikom savjetovanja mladih - suvremenih generacija, stručnjaci da bi procijenili normativnost u kontekstu odrastanja (npr. online dopisivanje i dijeljenje sadržaja) trebali bi biti informirani o kulturnim normama povezanim s uporabom društvenih mreža, a i kako bi utvrdili odstupanja od očekivanih iskustava (npr. vrijeđanje, dijeljenje sadržaja bez pristanka - elektroničko nasilje). O nesigurnosti u vlastito znanje govori činjenica da se $30 \%$ socijalnih radnika osjeća nesigurno prilikom postupanja u slučajevima zaštite online seksualno zlostavljane djece, a $74 \%$ ih ističe potrebu za većom podrškom u radu na takvim slučajevima (Bond i Dogaru, 2019). Slični podatci dobiveni su u Hrvatskoj vezano uz rizične oblike ponašanja, odnosno gotovo svi stručnjaci (93\%) iskazuju da bi željeli i da trebaju dodatnu edukaciju za svakodnevni rad. Stručnjaci dodatnim educiranjem mogu steći znanja i uvide o specifičnostima načina odrastanja u digitalnom dobu, a Pagnotta i suradnici (2018) su svojom studijom među prvima razmatrali dodavanje četvrte komponentne ovom modelu - a to je kompetencija digitalne pismenosti. Veći broj istraživanja upozorava da se djeca i mladi ne povjeravaju odraslima, primjerice $90 \%$ adolescenata ne prijavljuje iskustva nasilja na internetu odraslima, ponajviše zato što vjeruju da odrasli neće razumjeti ili odgovoriti na odgovarajući način (Gao, Zhao i McJunkin, 2016). Rezultati istraživanja u Hrvatskoj pokazuju da gotovo polovina djece koja su imala uznemirujuća iskustva na internetu nikad ili gotovo nikad nije zatražila potporu i pomoć roditelja u vezi sa situacijama i problemima koji su ih uznemirili dok su bili na internetu (Ciboci i sur., 2020), više od polovine mladih o sekstingu ne razgovara ni s kim, oko trećine mladih razgovara s prijateljima, $2,8 \%$ s roditeljima, 2,2\% s nekim putem interneta, a $0,3 \%$ sa stručnjacima u školi; $80 \%$ stručnjaka iz stručnih službi srednje škole navodi da im se nitko od učenika prvog i drugog razreda, odnosno gotovo $90 \%$ učenika trećeg i četvrtog razreda škole nikad nije povjerilo vezano uz seksting. Slični podatci dobiveni su i za seksualno iznuđivanje - u prvom i drugom razredu nitko se nije povjerio 93\% stručnjaka, a u trećem i četvrtom razredu srednje škole razredu nitko se nije povjerio gotovo 97\% stručnjaka (Poliklinika za zaštitu djece i mladih Grada Zagreba, 2019), a što nedvojbeno govori o diskrepanciji između doživljavanja navedenih iskustava i povjeravanja odraslima. 
Druga komponenta ovog modela odnosi se na svjesnost stručnjaka o vlastitim uvjerenjima, pretpostavkama i stavovima koji mogu voditi do pristranosti u radu. Primjerice, stručnjaci koji rade $s$ djecom i mladima mogu imati vlastite stavove i uvjerenja da online seksualno zlostavljanje dovodi do manje psihološke štete unatoč tomu što je u brojnim recentnim istraživanjima utvrđeno da su posljedice za mentalno zdravlje jednake onima koje imaju djeca koja su doživjela seksualno zlostavljanje (Jonsson i sur., 2019). Navedene osobne procjene i uvjerenja stručnjaka u konačnici mogu dovesti do manje zabrinutosti za djecu koja se javljaju s takvim iskustvima u odnosu na djecu koja imaju iskustva klasičnog oblika seksualnog zlostavljanja (Hamilton-Giachritsis i sur., 2017; Joleby i sur., 2021). Nadalje, seksualno zlostavljanje na internetu nerijetko je podložno brojnim predrasudama čak i stručnjaka, popraćeno najviše poimanjem da je dijete, nema fizičkog počinitelja i stoga ima „izbor" (Hamilton-Giachritsis, 2020). Takve neadekvatne i prije svega štetne reakcije stručnjaka, uz samooptuživanje žrtve (što je tipična posljedica na emocionalnom planu), zasigurno će utjecati na vjerojatnost traženja pomoći i razotkrivanja, a time i na njihovu sposobnost pristupa odgovarajućoj podršci. Drugim riječima, poznavanje specifičnosti i karakteristika vrbovanja, čija je najvažnija značajka dugotrajna i snažna emocionalna veza sa zlostavljačem, zbog koje žrtve jesu ambivalentne oko povjeravanja, povećava vjerojatnost da će stručnjaci adekvatnije pružiti podršku djeci, jasno uvidjeti odnos moći odrasle osobe u tom odnosu, (Hamilton-Giachritsis, 2020) upravo kao i kod tradicionalnog oblika seksualnog zlostavljanja (Joleby i sur., 2021). Dakle, djetetovi ili adolescentovi poslani sadržaji rezultat su vrbovanja odrasle osobe te iako adolescenti mogu reći da su se u takav odnos upustili "dobrovoljno", zapravo je on posljedica manipulacije (De Santisteban i Gámez-Guadix, 2017), a i sa zakonskog aspekta se radi o kažnjivu zakonskom djelu za koje je isključivo odgovoran počinitelj (MUP, 2020).

Nadalje, treća komponenta multikulturalnosti, odnosno vještine, odnosi se na sposobnost stručnjaka da povećava učinkovitost u komuniciraju i pristupanju klijentima na primjeren način (Sue i Sue, 2003; prema Pagnotta i sur., 2018). Dakle, u odnosu na druga područja zaštite djece, u slučajevima seksualnog zlostavljanja i iskorištavanja putem interneta važna je i razina digitalne kompetencije stručnjaka u svrhu: predviđanja mogućih rizika od sigurnosti profila, procjene sigurnosti pojedine aplikacije, obavještavanja o kršenju pravila na pojedinoj društvenoj mreži, poučavanja o načinima i alatima očuvanja dokaza. Također, u konkretnim terminima to bi značilo da su stručnjaci dobro upućeni u različite platforme društvenih mreža kojima se njihovi korisnici/klijenti koriste, a sve da bi povećali vjerojatnost razvijanja odnosa i povjeravanja, zaštite i edukacije djeteta. S obzirom na saznanja da su aktualne statistike samo aproksimativne procjene i da je najveći broj slučajeva neprijavljen, odnosno velika je siva brojka, postojanje aplikacije Ministarstva unutarnjih poslova Red Button, putem koje se anonimno može prijaviti nasilje uživo ili na internetu bilo da prijavljuje sama žrtva ili svjedok, predstavlja značajan iskorak u obavještavanju nadležnih institucija o sumnji na kaznena djela posredovana modernim tehnologijama.

Uloga stručnjaka ponajprije se odnosi na vlastitu edukaciju o novim oblicima zlostavljanja djece, a potom na edukaciju djece i mladih kao i na koji način se zaštititi, ali i na upoznavanje djece s potencijalno rizičnim ponašanjima u koja se mogu uključiti na internetu (Van Ouytsel, Walrave i Van Gool, 2014), a što će u konačnici povećati i vjerojatnost povjeravanja mladih o iskustvima koje doživljavaju. Iz perspektive prevencije, navedeno osnažuje potrebu da se s mladima također radi na edukaciji kako i na koji način se suočiti s pritiskom vršnjaka u kontekstu sekstinga, odnosno raditi 
na razvijanju vještina sigurnosti korištenja društvenih mreža, odnosno onih koje ih mogu zaštititi u kontekstu online rizičnih ponašanja kao i općenito korištenja modernim tehnologijama (Gregg i sur., 2018). Sve intenzivnija uporaba suvremenih tehnologija već od predškolske dobi sugerira da se s programima edukacije i preventivnog djelovanja treba započeti već u vrtićkoj dobi s postupnim uvođenjem programa te ih kontinuirano provoditi u skladu s dobi djece tijekom cjelokupnog procesa obrazovanja.

\section{ZAKLJUČAK}

Svakodnevno i intenzivno korištenje digitalnim tehnologijama omogućilo je nove oblike seksualnog zlostavljanja i iskorištavanja djece putem interneta koji su trenutno nedovoljno proučavani, a rizici donekle podcijenjeni. Dakle, iako se na korištenje modernim tehnologijama nerijetko gleda kao na izazov odrastanja, važno ga je promatrati kroz prizmu ozbiljnih rizičnih ponašanja koja, ako dovedu do zlostavljanja, predstavljaju povredu prava i dostojanstva djeteta, odnosno kaznenih djela definiranih zakonom. Koliko su skromne trenutne spoznaje o prevalenciji navedenih oblika kojima je krovni pojam seksualno zlostavljanje i iskorištavanje svjedoči INTERPOL-ovo izvješće u kojemu se navodi da od evidentiranog seksualnog zlostavljanja putem interneta nad djecom trenutno vidimo samo vrh sante leda.

Budući da ni u svijetu, pa ni u Hrvatskoj ne postaje prevalencije spoznaje, za sada imamo trendove, koji upozoravaju na sustavna povećanja, potrebno je provesti brojna istraživanja koja promatraju ova rizična ponašanja putem interneta na način da za svako od njih postaje spoznaja o prevalenciji, prediktorima kao i rizičnim čimbenicima, kao i pojasniti njihova međudjelovanja te indikatore mentalnog zdravlja djece i mladih. Važno je naglasiti da je operacionalizacija konstrukata i uporaba istovjetne terminologije jedan od značajnih problema na kojem je potrebno raditi. Neizostavno je naglasiti da raznovrsna metodologija i operacionalizacija, iako ponekad omogućuju potencijalno širi uvid u spoznavanje fenomena, istovremeno snažno otežavaju sintezu dosad postojećih spoznaja te upozoravaju na snažnu diskrepanciju unutar istog područja istraživanja. Također, naredna istraživanja trebala bi se usredotočiti na istraživanje praktičnih i teorijskih načina na koje stručnjaci mogu odgovoriti na ove razvojne i pandemijske pomake u kontekstu odrastanja umjesto na donošenje vrijednosnih prosudbi vezanih uz rizike odrastanja u suvremenom dobu. Neizostavno je kao stav autora iznijeti da je edukacija stručnjaka i djece ključna, nužna i predstavlja jedan od preduvjeta za uspješno suzbijanje ovih vrsta nasilja nad djecom.

Premda se o raznim oblicima seksualnog zlostavljanja i iskorištavanja na internetu u stručnom diskursu govori već dulje vrijeme u doba pandemije ono je apelima etabliranih institucija kao što su INTERPOL i EUROPOL, koji pandemiju promatraju ne samo u svjetlu virusa COVID-19 već u već sada vidljivim posljedicama nasilja nad djecom posredovanim internetom, došlo u javni fokus. Podcijenjena prevalencija raznih oblika koje pripadaju seksualnom zlostavljanju i iskorištavanju djece putem interneta, uz nedostatak jasne terminologije stvaraju ozbiljne teškoće u razumijevanju ovih zlostavljajućih iskustava i uspostavljanje praksi zaštite. Dakle, aktivno suočavanje s prepoznavanjem i identificiranjem svih raznih oblika koji pripadaju krovnom pojmu seksualnog zlostavljanja i iskorištavanja djece na internetu, uzimajući u obzir sva navedena saznanja i s njima povezane rizike, 
u sve mjere prevencije i zaštite od COVID-19 moraju biti integriranje i sve mjere zaštite od seksualnog zlostavljanja i iskorištavanja djece na internetu, a što je odgovornost stručne i znanstvene zajednice. Hrvatska, kao i druge brojne zemlje potpisnice Konvencije Vijeća Europe o zaštiti djece od seksualnog iskorištavanja i seksualnog zlostavljanja, poznatoj kao Lanzarote konvencija, dužne su u svim aspektima osigurati implementaciju njezinih odredaba, posebno sada u tijeku pandemije.

\section{LITERATURA}

Ajduković, M. (2008). Socijalni problemi, socijalni rizici i suvremeni socijalni rad. Revija za socijalnu politiku, 15(3), 395-414. https://doi.org/10.3935/rsp.v15i3.791

Ajduković, M., Rajhvajn Bulat, L., Sušac N. i Vejmelka L. (2020). Subjektivna dobrobit djece u Hrvatskoj. UNICEF Hrvatska. Preuzeto s: https://www.unicef.org/croatia/media/5136/file/Subjektivna\%20dobrobit\%20djece\%20u\%20Hrvatskoj.pdf (30.10.2021.)

Ballester-Arnal, R., Giménez-García, C., Gil-Llario, M. D. i Castro-Calvo, J. (2016). Cybersex in the Net generation: Online sexual activities among Spanish adolescents. Computers in Human Behavior, 57, 261-266. http://doi.org/10.1016/j.chb.2015.12.036

Barrense-Dias, Y., Berchtold, A., Surís, J. C. i Akre, C. (2017). Sexting and the definition issue. Journal of Adolescent Health, 61(5), 544-554. https://doi.org/10.1016/j.jadohealth.2017.05.009

Baumgartner, S. E., Sumter, S. R., Peter, J. i Valkenburg, P. M. (2012). Identifying teens at risk: Developmental pathways of online and offline sexual risk behavior. Pediatrics, 130(6), e1489-e1496. https://doi.org/10.1542/peds.2012-0842

Baumgartner, S. E., Sumter, S. R., Peter, J., Valkenburg, P. M. i Livingstone, S. (2014). Does country context matter? Investigating the predictors of teen sexting across Europe. Computers in $\mathrm{Hu}$ man Behavior, 34, 157-164. https://doi.org/10.1016/j.chb.2014.01.041

Bergen, E., Davidson, J., Schulz, A., Schuhmann, P., Johansson, A., Santtila, P., et al. (2014). The effects of using identity deception and suggesting secrecy on the outcomes of adult-adult and adultchild or adolescent online sexual interactions. Victims and Offenders, 9(3), 276-298. https://doi. org/10.1080/15564886.2013.873750.

Bianchi, D., Morelli, M., Baiocco, R. i Chirumbolo, A. (2017). Sexting as the mirror on the wall: body-esteem attribution, media models, and objectified-body consciousness. Journal of Adolescence, 61, 164-172.

Bianchi, D., Morelli, M., Nappa, M. R., Baiocco, R. i Chirumbolo, A. (2018). A bad romance: sexting motivations and teen dating violence. Journal of interpersonal violence, 36(13-14). https://doi. org/10.1177/0886260518817037

Bond, E. i Dogaru, C. (2019). An evaluation of an inter-disciplinary training programme for professionals to support children and their families who have been sexually abused online. The British Journal of Social Work, 49(3), 577-594. https://doi.org/10.1093/bjsw/bcy075

Brewer, G. i Kerslake, J. (2015). Cyberbullying, self-esteem, empathy and loneliness. Computers in human behavior, 48, 255-260. https://doi.org/10.1016/j.chb.2015.01.073 
Ana Raguž, Gordana Buljan Flander, Vlatka Boričević Maršanić: Uporaba modernih tehnologija kao rizik za...

Brochado, S., Soares, S. i Fraga, S. (2017). A scoping review on studies of cyberbullying prevalence among adolescents. Trauma, Violence, \& Abuse, 18(5), 523-531. https://doi. org/10.1177/1524838016641668

Burén, J. i Lunde, C. (2018). Sexting among adolescents: A nuanced and gendered online challenge for young people. Computers in Human Behavior, 85, 210-217. https://doi.org/10.1016/j. chb.2018.02.003

Chang, F. C., Chiu, C. H., Miao, N. F., Chen, P. H., Lee, C. M. i Chiang, J. T. (2016). Predictors of unwanted exposure to online pornography and online sexual solicitation of youth. Journal of Health Psychology, 21(6), 1107-1118. http://doi.org/10.1177/1359105314546775

Chun, J. Lee, J., Kim, J. i Lee, S. (2020). An international systematic review of cyberbullying measurements. Computers in human behavior, 106485. https://doi:10.1016/j.chb.2020.106485

Ciboci, L., Ćosić Pregrad, I., Kanižaj, I., Potočnik, D. i Vinković D. (2020). Nacionalno istraživanje o sigurnosti djece na internetu HR Kids Online. Društvo za komunikacijsku i medijsku kulturu. Preuzeto s: http://hrkids.online/prez/EUKidsOnlineHRfinal.pdf (16.10.2020.)

Cooper, K., Quayle, E., Jonsson, L. i Svedin, C. G. (2016). Adolescents and self-taken sexual images: A review of the literature. Computers in human behavior, 55, 706-716. https://doi.org/10.1016/j. chb.2015.10.003

Craven, S., Brown, S. i Gilchrist, E. (2006). Sexual grooming of children: Review of literature and theoretical considerations. Journal of Sexual Aggression, 12(3), 287-299. http://dx.doi. org/10.1080/13552600601069414

De Santisteban, P. i Gámez-Guadix, M. (2018). Prevalence and risk factors among minors for online sexual solicitations and interactions with adults. The Journal of Sex Research, 55, 939-950. https://doi.org/10.1080/00224499.2017.138676

De Santisteban, P., del Hoyo, J., Alcázar-Córcoles, M.Á. i Gámez-Guadix, M. (2018). Progression, maintenance, and feedback of online child sexual grooming: A qualitative analysis of online predators. Child Abuse \& Neglect, 80, 203-215. https://doi.org/10.1016/j.chiabu.2018.03.026

Dönmez, Y. E. i Soylu, N. (2019). Online sexual solicitation in adolescents; socio-demographic risk factors and association with psychiatric disorders, especially posttraumatic stress disorder. Journal of psychiatric research, 117, 68-73. https://doi.org/10.1016/j.jpsychires.2019.07.002

Englander, E. K. i McCoy, M. (2017). Pressured sexting and revenge porn in a sample of Massachusetts adolescents. International Journal of Technoethics (IJT), 8(2), 16-25.

EUROPOL (2020). Child sexual exploitation. Preuzeto s: $h$ ttps://www.europol.europa.eu/crime-areasand-trends/crime-areas/child-sexual-exploitation (30.09.2021.)

EUROPOL (2020). Exploiting isolation: offenders and victims of online child sexual abuse during the covid-19 pandemic. Preuzeto s: $h$ ttps://www.europol.europa.eu/publications-documents/exploiting-isolation-offenders-and-victims-of-online-child-sexual-abuse-during-covid-19-pandemic (30.10.2021.)

Fink Finkelhor, D., Ormrod, R. K. i Turner, H. A. (2007). Poly-victimization: A neglected component in child victimization. Child abuse \& neglect, 31(1), 7-26. https://doi.org/10.1016/j.chiabu.2006.06.008 
Gámez-Guadix, M. i Mateos-Pérez, E. (2019). Longitudinal and reciprocal relationships between sexting, online sexual solicitations, and cyberbullying among minors. Computers in Human Behavior, 94, 70-76. https://doi.org/10.1016/j.chb.2019.01.004

Gámez-Guadix, M., Almendros, C., Borrajo, E. i Calvete, E. (2015). Prevalence and association of sexting and online sexual victimization among Spanish adults. Sexuality Research and Social Policy, 12(2), 145-154. https://doi.org/10.1007/s13178-015-0186-9

Gámez-Guadix, M., Almendros, C., Calvete, E. i De Santisteban, P. (2018). Persuasion strategies and sexual solicitations and interactions in online sexual grooming of adolescents: Modeling direct and indirect pathways. Journal of Adolescence, 63, 11-18. https://doi.org/10.1016/j. adolescence.2017.12.002

Gámez-Guadix, M., Borrajo, E. i Almendros, C. (2016). Risky online behaviors among adolescents: Longitudinal relations among problematic Internet use, cyberbullying perpetration, and meeting strangers online. Journal of Behavioral Addictions, 5, 100-107. http://dx.doi. org/10.1556/2006.5.2016.013

Gámez-Guadix, M., De Santisteban, P. i Alcazar, M. Á. (2018). The construction and psychometric properties of the questionnaire for online sexual solicitation and interaction of minors with adults. Sexual Abuse, 30(8), 975-991. https://doi.org/10.1177/1079063217724766

Gómez, P., Rial, A., Braña, T., Golpe, S. i Varela, J. (2017). Screening of Problematic Internet Use among Spanish adolescents: Prevalence and related variables. Cyberpsychology, Behavior, and Social Networking, 20(4), 259-267. https://doi.org/10.1089/cyber.2016.0262

Greene-Colozzi, E. A., Winters, G. M., Blasko, B. i Jeglic, E. L. (2020). Experiences and perceptions of online sexual solicitation and grooming of minors: a retrospective report. Journal of child sexual abuse, 29(7), 836-854.

Gregg, D., Somers, C. L., Pernice, F. M., Hillman, S. B. i Kernsmith, P. (2018). Sexting rates and predictors from an urban midwest high school. Journal of School Health, 88(6), 423-433. https:// doi.org/10.1111/josh.12628

Haddon, L. i Livingstone, S. (2012). EU Kids Online: national perspectives. Preuzeto s: http://eprints. Ise.ac.uk/46878/ (2.11.2020.)

Hamilton-Giachritsis, C., Hanson, E., Whittle, H. C. i Beech, A. R. (2017). Everyone deserves to be happy and safe. A mixed methods study exploring how online and offline child sexual abuse impact young people and how professionals respond to it. Preuzeto s: https://www.researchgate.net/profile/Elly_Hanson/publication/326827010_Everyone_deserves_to_be_happy_and_ safe_A_mixed_methods_study_exploring_how_online_and_offline_child_sexual_abuse_impact_young_people_and_how_professionals_respond_to_it/links/5b656970a6fdcc94a70c69ee/ Everyone-deserves-to-be-happy-and-safe-A-mixed-methods-study-exploring-how-online-andoffline-child-sexual-abuse-impact-young-people-and-how-professionals-respond-to-it.pdf (10.11.2020.)

Hamilton-Giachritsis, C., Hanson, E., Whittle, H., Alves-Costa, F., Pintos, A., Metcalf, T. i Beech, A. (2020). Technology assisted child sexual abuse: Professionals' perceptions of risk and impact on children and young people. Child Abuse \& Neglect, 104651. https://doi.org/10.1016/j. chiabu.2020.104651

Hinduja, S. i Patchin, J. W. (2011). High-tech cruelty. Educational Leadership, 68(5), 48-52. 
Ana Raguž, Gordana Buljan Flander, Vlatka Boričević Maršanić: Uporaba modernih tehnologija kao rizik za...

Holloway, D., Green, L. i Livingstone, S. (2013). Zero to eight. Young children and their internet use. LSE, London: EU Kids Online. Preuzeto s: https://ro.ecu.edu.au/cgi/viewcontent.cgi?article= 1930\&context=ecuworks2013 (2.11.2020.)

Hrabri telefon i Poliklinika za zaštitu djece grada Zagreba (2013). Istraživanje o iskustvima i ponašanjima djece na Internetu i na društvenoj mreži Facebook. Preuzeto s: $h$ ttps://www.poliklinika-djeca. hr/istrazivanja/istrazivanje-o-iskustvima-i-ponasanjima-djece-na-internetu-i-na-drustvenoj-mrezi-facebook-2/ (27.10.2020.)

Interagency Working Group on Sexual Exploitation of Children (2016). Terminology guidelines for the protection of children from sexual exploitation and sexual abuse. ECPAT International \& ECPAT Luxembourg. Preuzeto s: http://luxembourgguidelines.org/ (27.10.2020.)

INTERPOL (2020). Threats and trends child sexual exploitation and abuse". COVID-19 impact. Preuzeto s: https://www.interpol.int/content/download/15611/file/COVID19\%20-\%20Child\%20Sexual\%20 Exploitation\%20and\%20Abuse\%20threats\%20and\%20trends.pdf (20.09.2021.)

Jurinić, J., Vejmelka, L. i Galiot, M. (2020). Seksualno iskorištavanje djece na internetu: od povijesnog prikaza do suvremenih trendova. Policija i sigurnost, 29(4), 404-425.

Jasso, J. L., López, F. i Gámez-Guadix, M. (2018). Assessing the links of sexting, cybervictimization, depression, and suicidal ideation among university students. Archives of Suicide Research, 22, 153-164. https://doi.org/10.1080/13811118.2017.1304304

Joleby, M., Landström, S., Lunde, C. i Jonsson, L. S. (2021). Experiences and psychological health among children exposed to online child sexual abuse-a mixed methods study of court verdicts. Psychology, Crime \& Law, 27(2), 159-181. https://doi.org/10.1080/1068316X.2020.1781120

Jonsson, L. S., Fredlund, C., Priebe, G., Wadsby, M. i Svedin, C. G. (2019). Online sexual abuse of adolescents by a perpetrator met online: A cross-sectional study. Child and Adolescent Psychiatry and Mental Health, 13(1), 32. https://doi.org/10.1186/s13034-019-0292-1

Jørgensen, C. R., Weckesser, A., Turner, J. i Wade, A. (2019). Young people's views on sexting education and support needs: findings and recommendations from a UK-based study. Sex Education, 19(1), 25-40. https://doi.org/10.1080/14681811.2018.1475283

Klettke, B., Hallford, D. J., Clancy, E., Mellor, D. J. i Toumbourou, J. W. (2019). Sexting and psychological distress: The role of unwanted and coerced sexts. Cyberpsychology, Behavior, and Social Networking, 22(4), 237-242. https://doi.org/10.1089/cyber.2018.0291

Kloess, J. A., Beech, A. R. i Harkins, L. (2014). Online child sexual exploitation: Prevalence, process, and offender characteristics. Trauma, Violence, \& Abuse, 15, 126-139. http://dx.doi. org/10.1177/1524838013511543

Konvencija Vijeća Europe o zaštiti djece od seksualnog iskorištavanja i seksualnog zlostavljanja (2007). Preuzeto s: https://rm.coe.int/CoERMPublicCommonSearchServices/DisplayDCTMContent?documentld $=090000168046 e 1 d 1$ (20.09.2021.)

Kowalski, R. M., Giumetti, G. W., Schroeder, A. N. i Lattanner, M. R. (2014). Bullying in the digital age: A critical review and meta-analysis of cyberbullying research among youth. Psychological Bulletin, 140, 1073-1137. https://doi.org/10.1037/a0035618

Kričkić, D., Šincek, D. i Babić Čike, A. (2017). Sexting, cyber-violence and sexually risk behaviour among college students. Kriminologija \& socijalna integracija, 25(2), 15-28. https://doi.org/10.31299/ ksi.25.2.2 
Livingstone, S. i Smith, P. K. (2014). Annual research review: Harms experienced by child users of online and mobile technologies: The nature, prevalence and management of sexual and aggressive risks in the digital age. Journal of child psychology and psychiatry, 55(6), 635-654. https:// doi.org/10.1111/jcpp.1219

Livingstone, S., Haddon, L., Görzig, A. i Ólafson, K. (2011). EU kids online II: Final report. Preuzeto s: http://eprints.lse.ac.uk/39351/1/EU_kids_online_final_report_\%5BLSERO\%5D.pdf (28.11.2020).

Livingstone, S., Haddon, L., Görzig, A. i Ólafsson, K. (2011). Risks and safety on the internet: the perspective of European children: full findings and policy implications from the EU Kids Online survey of 9-16 year olds and their parents in 25 countries. Preuzeto s: http://eprints.lse.ac.uk/33731/1/ Risks\%20and\%20safety\%20on\%20the\%20internet(lsero).pdf (25.10.2020.)

Machimbarrena, J. M. i Garaigordobil, M. (2018). Prevalence of bullying and cyberbullying in the last stage of primary education in the Basque Country. The Spanish journal of psychology, 21(48), 1-10. https://doi.org/10.1017/sjp.2018.41

Machimbarrena, J. M., Calvete, E., Fernández-González, L., Álvarez-Bardón, A., Álvarez-Fernández, L. i González-Cabrera, J. (2018). Internet risks: An overview of victimization in cyberbullying, cyber dating abuse, sexting, online grooming and problematic internet use. International journal of environmental research and public health, 15(11), 2471. https://doi.org/10.3390/ijerph15112471

Madigan, S., Ly, A., Rash, C. L., Van Ouytsel, J. i Temple, J. R. (2018). Prevalence of multiple forms of sexting behavior among youth: A systematic review and meta-analysis. JAMA pediatrics, 172(4), 327-335. https://doi.org/10.1001/jamapediatrics.2017.5314

Maheux, A. J., Evans, R., Widman, L., Nesi, J., Prinstein, M. J. i Choukas-Bradley, S. (2020). Popular peer norms and adolescent sexting behavior. Journal of Adolescence, 78, 62-66. https://doi. org/10.1016/j.adolescence.2019.12.002

Ministarstvo unutarnjih poslova (2020). Zlostavljanje suvremenim tehnologijama mobitel i Internet. Preuzeto s: https://mup.gov.hr/gradjani-281562/savjeti-281567/nasilje-281582/zlostavljanje-. suvremenim-tehnologijama-mobitel-i-internet-12214/12214 (27.11.2020.)

Mitchell, K. J., Finkelhor, D. i Wolak, J. (2007). Online requests for sexual pictures from youth: Risk factors and incident characteristics. Journal of Adolescent Health, 41(2), 196-203. https://doi. org/10.1016/j.jadohealth.2007.03.013

Mitchell, K. J., Finkelhor, D., Jones, L. M. i Wolak, J. (2012). Prevalence and characteristics of youth sexting: A national study. Pediatrics, 129(1), 13-20. http://doi.org/10.1542/peds.2011-1730

Mitchell, K. J., Wolak, J. i Finkelhor, D. (2007). Trends in youth reports of sexual solicitations, harassment and unwanted exposure to pornography on the Internet. Journal of adolescent health, 40(2), 116-126. https://doi.org/10.1016/j.jadohealth.2006.05.021

Morelli, M., Bianchi, D., Baiocco, R., Pezzuti, L. i Chirumbolo, A. (2016). Not-allowed sharing of sexts and dating violence from the perpetrator's perspective: The moderation role of sexism. Computers in human behavior, 56, 163-169. https://doi.org/10.1016/j.chb.2015.11.047

MUP (2021). Zlostavljanje suvremenim tehnologijama - mobitel $i$ Internet. Preuzeto s: $h$ ttps://mup. gov.hr/gradjani-281562/savjeti-281567/nasilje-281582/zlostavljanje-suvremenim-tehnologijama-mobitel-i-internet-12214/12214 (20.09.2021.) 
Ana Raguž, Gordana Buljan Flander, Vlatka Boričević Maršanić: Uporaba modernih tehnologija kao rizik za...

Notten, N. i Nikken, P. (2016). Boys and girls taking risks online: A gendered perspective on social context and adolescents' risky online behavior. New Media \& Society, 18(6), 966-988. https:// doi.org/10.1177/1461444814552379

Nur Say, G., Babadagi, Z., Karabekiroglu, K., Yüce, M. i Akbas, S. (2015). Abuse characteristics and psychiatric consequences associated with online sexual abuse. Cyberpsychology, Behavior and Social Networking, 18, 333-336. https://doi.org/10.1089/cyber.2014.0494

Pagnotta, J., Blumberg, F. C., Ponterotto, J. G. i Alvord, M. K. (2018). Adolescents' perceptions of their therapists' social media competency and the therapeutic alliance. Professional Psychology: Research and Practice, 49(5-6), 336-344. https://doi.org/10.1037/pro0000219

Paolucci, E. O., Genuis, M. L. i Violato, C. (2001). A meta-analysis of the published research on the effects of child sexual abuse. Journal of Psychology, 135, 17-36. https://doi.org/10.1080/00223980109603677

Patchin, J. W. i Hinduja, S. (2020). Sextortion among adolescents: results from a national survey of US youth. Sexual Abuse, 32(1), 30-54. https://doi.org/10.1177/1079063218800469.

Poliklinika za zaštitu djece i mladih Grada Zagreba (2019). Rezultati nacionalnog istraživačkog projekta "Društvena online iskustva i mentalno zdravlje mladih". Preuzeto s: https://www.poliklinika-djeca. hr/istrazivanja/rezultati-nacionalnog-istrazivackog-projekta-drustvena-online-iskustva-i-mentalno-zdravlje-mladih/ (28.10.2020.)

Reyns, B. W., Burek, M. W., Henson, B. i Fisher, B. S. (2013). The unintended consequences of digital technology: Exploring the relationship between sexting and cybervictimization. Journal of Crime and Justice, 36(1), 1-17. https://doi.org/10.1080/0735648X.2011.641816

Roje Đapić, M., Buljan Flander, G. i Selak Bagarić, E. (2020). Mala djeca pred malim ekranima: Hrvatska u odnosu na Europu i svijet. Napredak: Časopis za interdisciplinarna istraživanja u odgoju i obrazovanju, 161(1-2), 45-61.

Schneider, S. K., O'Donnell, L., Stueve, A. i Coulter, R. W. (2012). Cyberbullying, school bullying, and psychological distress: A regional census of high school students. American journal of public health, 102(1), 171-177.

Shariff, S. i Gouin, R. (2006). Cyber-dilemmas: Gendered hierarchies, new technologies and cyber-safety in schools. Atlantis: Critical Studies in Gender, Culture \& Social Justice, 31(1), 27-37.

Shelton, J., Eakin, J., Hoffer, T., Muirhead, Y. i Owens, J. (2016). Online child sexual exploitation: An investigative analysis of offender characteristics and offending behavior. Aggression and violent behavior, 30, 15-23. https://doi.org/10.1016/j.avb.2016.07.002

Sklenarova, H., Schulz, A., Schuhmann, P., Osterheider, M. i Neutze, J. (2018). Online sexual solicitation by adults and peers - Results from a population based German sample. Child Abuse \& Neglect, 76, 225-236. https://doi.org/10.1016/j.chiabu.2017.11.005

Smahel, D., Machackova, H., Mascheroni, G., Dedkova, L., Staksrud, E., Ólafsson, K., Livingstone, S. i Hasebrink, U. (2020). EU Kids Online 2020: Survey results from 19 countries. EU Kids Online. https://doi.org/10.21953/lse.47fdeqj01ofo

Starcevic, V. i Aboujaoude, E. (2015). Cyberchondria, cyberbullying, cybersuicide, cybersex: "new" psychopathologies for the 21st century?. World Psychiatry, 14(1), 97. 
Strassberg, D. S., Rullo, J. E. i Mackaronis, J. E. (2014). The sending and receiving of sexually explicit cell phone photos ("sexting") while in high school: One college's students' retrospective reports. Computers in Human Behavior, 41, 177-183. https://doi.org/10.1016/j.chb.2014.09.008

Temple, J. R., Le, V. D., van den Berg, P., Ling, Y., Paul, J. A. i Temple, B. W. (2014). Brief report: Teen sexting and psychosocial health. Journal of Adolescence, 37, 33-36. https://doi.org/10.1016/j. adolescence.2013.10.008

Van Gijn-Grosvenor, E. L. i Lamb, M. E. (2016). Behavioural differences between online sexual groomers approaching boys and girls. Journal of child sexual abuse, 25(5), 577-596. https://doi.org/10 $.1080 / 10538712.2016 .1189473$

Van Oosten, J. M., Vandenbosch, L. i Peter, J. (2017). Gender roles on social networking sites: investigating reciprocal relationships between Dutch adolescents' hypermasculinity and hyperfemininity and sexy online self-presentations. Journal of Children and Media, 11(2), 147-166. https:// doi.org/10.1080/174882798.2017.1304970

Van Ouytsel, J., Lu, Y., Ponnet, K., Walrave, M. i Temple, J. R. (2019). Longitudinal associations between sexting, cyberbullying, and bullying among adolescents: Cross-lagged panel analysis. Journal of adolescence, 73, 36-41. https://doi.org/10.1016/j.adolescence.2019.03.008

Van Ouytsel, J., Ponnet, K. i Walrave, M. (2018). Cyber dating abuse victimization among secondary school students from a lifestyle-routine activities theory perspective. Journal of interpersonal violence, 33(17), 2767-2776. https://doi.org/10.1177/0886260516629390

Van Ouytsel, J., Ponnet, K., Walrave, M. i d'Haenens, L. (2017). Adolescent sexting from a social learning perspective. Telematics and Informatics, 34(1), 287-298. https://doi.org/10.1016/j.tele.2016.05.009

Van Ouytsel, J., Van Gool, E., Walrave, M., Ponnet, K. i Peeters, E. (2017). Sexting: adolescents' perceptions of the applications used for, motives for, and consequences of sexting. Journal of Youth Studies, 20(4), 446-470. https://doi.org/10.1080/13676261.2016.1241865

Van Ouytsel, J., Walrave, M. i Ponnet, K. (2019). Sexting within adolescents' romantic relationships: How is it related to perceptions of love and verbal conflict?. Computers in Human Behavior, 97, 216-221. https://doi.org/10.1016/j.chb.2019.03.029

Van Ouytsel, J., Walrave, M. i Van Gool, E. (2014). Sexting: Between thrill and fear-How schools can respond. The Clearing House: A Journal of Educational Strategies, Issues and Ideas, 87(5), 204212. https://doi.org/10.1080/00098655.2014.918532

Van Ouytsel, J., Walrave, M., Lu, Y., Temple, J. R. i Ponnet, K. (2018). The associations between substance use, sexual behavior, deviant behaviors and adolescents' engagement in sexting: does relationship context matter? Journal of youth and adolescence, 47(11), 2353-2370.

Van Ouytsel, J., Walrave, M., Ponnet, K. i Heirman, W. (2015). The association between adolescent sexting, psychosocial difficulties, and risk behavior: Integrative review. Journal of School Nursing, 31(1), 54-69. https://doi.org/10.1177/1059840514541964

Vandebosch, H. i Van Cleemput, K. (2008). Defining cyberbullying: A qualitative research into the perceptions of youngsters. CyberPsychology \& Behavior, 11(4), 499-503. https://doi.org/10.1089/ cpb.2007.0042

Vannucci, A., Simpson, E. G., Gagnon, S. i Ohannessian, C. M. (2020). Social media use and risky behaviors in adolescents: a meta-analysis. Journal of Adolescence, 79, 258-274. https://doi. org/10.1016/j.adolescence.2020.01.014 
Vejmelka, L. i Jurinić, J. (2020). Terminologija i konceptualizacija seksualnog iskorištavanja djece na internetu. Kriminologija \& socijalna integracija: časopis za kriminologiju, penologiju i poremećaje u ponašanju, 28(1), 95-114. https://doi.org/10.31299/ksi.28.1.5

Wachs, S., Whittle, H. C., Hamilton-Giachritsis, C., Wolf, K. D., Vazsonyi, A. T. i Junger, M. (2017). Correlates of mono-and dual-victims of cybergrooming and cyberbullying: Evidence from four countries. Cyberpsychology, Behavior, and Social Networking, 21. https://doi.org/10.1089/ cyber.2016.0733

Walker, K. i Sleath, E. (2017). A systematic review of the current knowledge regarding revenge pornography and non-consensual sharing of sexually explicit media. Aggression and violent behavior, 36, 9-24. https://doi.org/10.1016/j.avb.2017.06.010

Walker, S., Sanci, L. i Temple-Smith, M. (2013). Sexting: Young women's and men's views on its nature and origins. Journal of Adolescent Health, 52(6), 697-701. https://doi.org/10.1016/j. jadohealth.2013.01.026

Whittle, H., Hamilton-Giachritsis, C., Beech, A. i Collings, G. (2013). A review of young people's vulnerabilities to online grooming. Aggression and violent behavior, 18(1), 135-146. https://doi. org/10.1016/j.avb.2012.11.008

Wolak, J., Finkelhor, D., Mitchell, K. J. i Ybarra, M. L. (2010). Online "predators" and their victims: Myths, realities, and implications for prevention and treatment. Psychology of Violence, 1(S), 13-35. https://doi.org/10.1037/2152-0828.1.S.13

Wolak, J., Finkelhor, D., Walsh, W. i Treitman, L. (2018). Sextortion of minors: Characteristics and dynamics. Journal of Adolescent Health, 62(1), 72-79. https://doi.org/10.1016/j.jadohealth.2017.08.014

World Health Organisation (2003). Guidelines for medico-legal care for victims of sexual violence. Preuzeto s: https://www.who.int/violence_injury_prevention/publications/violence/med_leg_guidelines/en/ (20.09.2021.)

Wurtele, S. K. i Kenny, M. C. (2016). Technology-related sexual solicitation of adolescents: A review of prevention efforts. Child abuse review, 25(5), 332-344. https://doi.org/10.1002/car.2445

Žganec, N. i Miljenović, A. (2011). Multikulturalizam u socijalnom radu. Revija za socijalnu politiku, 18(3), 311-330. 


\title{
USE OF MODERN TECHNOLOGIES AS RISK FOR ONLINE-FACILITATED SEXUAL ABUSE AND EXPLOITATION OF CHILDREN AND ADOLESCENTS
}

\author{
Ana Raguž \\ Gordana Buljan Flander \\ Vlatka Boričević Maršanić \\ Child and Youth Protection Center of Zagreb
}

\begin{abstract}
The development of technology in the last twenty years has undoubtedly changed our way of life and thus the way children and young people grow up. Internet has become an integral part of everyday life activities. In this paper, risky online activities will be considered through various concepts: sexting, as an exchange of sexual content, sexual extortion of children (also called sextortion) as extortion of sexual content, and grooming process. All risks will be analyzed in detail in the context of online-facilitated child sexual abuse and exploitation through interrelationships between these concepts, consequences for mental health as well as the role of professionals from a multicultural perspective. Both the growing advancement of modern technologies and opportunities it brings, especially during the pandemic, are fertile ground for serious threats to mental health of children and youth. This also means that all those involved in child and youth protection need to create and develop new child protection systems.
\end{abstract}

Keywords: online-facilitated child sexual abuse and exploitation, online risk sexual behaviour, mental health, pandemic, professionals 